\title{
Inheemswording en inkulturasie: Implikasies vir teologie en kerk
}

\author{
P J van der Merwe \\ Departement Godsdiens- en Sendingwetenskap (Afd A) \\ Universiteit van Pretoria
}

\begin{abstract}
Indigenisation and inculturation: Implications for theology and church

Although the intimate bond between Church and culture was realised quite early on, it only became a theological issue after missionaries like Xavier, Ricci and DeNobili experimented with accommodation and adaptation in the East. In the 20th century their ideas surfaced again in the concepts of indigenisation and inculturation, that is, of Church and theology amongst peoples and cultures of the Third World. This development led Western theology to realise how historically and culturally contextualised Western ecclesiastical, doctrinal and theological traditions actually were. This in turn led to a fundamental rethinking on Church and culture, and again, on contextualisation; indigenisation and inculturation as missionary principles.
\end{abstract}

\section{INLEINDING}

Die samehang tussen kerk en kultuur het die afgelope klompie dekades herhaaldelik as 'n teologiese tema opgeduik en sal waarskynlik voortgaan om dit te doen, om die eenvoudige rede dat dit die wese van die kerk ten nouste raak. Namate daar oor die aard van kultuur as menslike verskyningsvorm besin is, is begryp dat dit nie net die religieusiteit en uiterlike vorme van die kerk raak nie, maar ook die begrippeskat, kennis en denke van diegene wat die kerk uitmaak (Van der Merwe 1996:681). Die kerk is self immers ook kultuurverskynsel, nie alleen vanweë die kerk se impak op kultuur nie, maar ook omdat die kerk nie anders kan as om deel van kultuur te wees nie.

Vir sover kerk as godsdiens bedink moet word, moet die woorde van Krüger in aanmerking geneem word:

... religion is not a separate sphere of experience with a separate object of experience. It is the widest expansion, the deepest penetration of consciousness. To follow this trend as far as possible, is the demand of reli- 
gion. It is an intension (sic) and extension of ordinary life, science and art, the tendency towards truth, beauty and goodness taken to the limit of comprehensiveness and radicality.

(Krüger 1988:212)

'n Mens sou deur die andersoortigheid van kerklike en teologiese taal, van 'n eiesoortige kerklike 'kultuur' en die geneigdheid om die kerk as iets aparts te beskou, verlei kon word om te dink dat die kerk inderdaad naas of teenoor die kultuur leef. Dit is egter net in 'n sekere sin waar. Daar is trouens ' $n$ subtiele interafhanklikheid wat alle kultuurverskynsels op een of ander wyse aan mekaar bind en waarvan ons die volle omvang en betekenis slegs kan raai, omdat ons self vasgevang is in die 'conditionalist web' waarvan Krüger op 'n ander plek praat (Krüger 1995:34).

Hierdie waarheid is geen nuwe insig nie en is trouens van vroegsaf intuïtief begryp en geëksploiteer. Dit word ironies genoeg egter 'n teologiese probleem wanneer sendelinge probeer om die sendingmetodes van adaptasie en verinheemsing daarop te baseer.

\section{HISTORIESE OORSIG}

Ons kyk vervolgens kursories na die ontwikkeling van die wisselwerkende verhouding tussen kerk en kultuur soos dit in die geskiedenis van die kerk en sending na vore kom.

\subsection{Vanaf inkarnasie tot kultuurpropaganda}

Verskeie sendingwetenskaplike skrywers maak die stelling dat die vroeë kerk en veral Paulus intuitief begryp het dat die evangelie en kerk nie anders kan uitbrei en groei as om 'n plaaslike kulturele verskyningsvorm aan te neem nie. Indien die Judaïseerders by die Apostelkonvent hulle sin gekry het, sou die kerk 'n Joodse sekte gebly het. Sake het egter anders verloop. Paulus het die konvent oorgehaal om wyer te kyk as die Jode en Joodse kultuur en religieusiteit. Hillman (1987:511) noem die ontwikkeling wat na Apostelkonvent volg, die eerste epogmakige vleeswording van die kerk 'in ephemeral cultural forms and social structures'. Die wêreld waarin die vroeë kerk gebore is, was 'n multikulturele een. Daarom was die oorskryding van kultuurgrense en 'vertaling' 'n normale sosiale gegewenheid.

Bosch $(1991: 448)$ voeg hierby dat daar van sentralisasie in die vroeë kerk nie veel sprake was nie. Die kerk het in plaaslike gemeentes vorm aangeneem, ofskoon daar steeds vasgehou is aan die idee van 'n gemeenskaplike kerklike liggaam. Dit het dus 
heelwat ruimte gelaat vir plaaslike interpretasies en uitdrukkings van die geloof. Roland Allen het reeds in 1913 met verwondering geskryf oor Paulus se sendingmetode en die vertroue wat hy gehad het dat die gemeentes wat hy gestig het, self hulle weg sou vind (Allen [1913], 1962).

Namate die sending van die vroeë kerk in momentum toegeneem het en die statistiese oorwig van Joodse Christene na Hellenistiese Christene verskuif het, het die teologiese swaartepunt ook verskuif. Van Aarde (1994:353) sê hieroor: '(Dit bly) 'n omstrede en belangrike vraag in watter mate die oorgang van die evangelie vanuit Palestina as geboortegrond na die Romeins-Griekse wêreld verandering in die formulering van die teologiese kernwaardes meegebring het. Met hierdie probleem worstel Bybelwetenskaplikes al vir dekades'.

'n Interessante feit van die vroeë teologiese ontwikkeling was dat terwyl Christene hulle skerp afgegrens het teen die ritueel-religieuse aspek van die omringende Hellenistiese kultuur, hulle van vroegsaf met vrymoedigheid gebruik gemaak het van idees, konsepte, paradigmata en filosofiese stelsels wat in dieselfde kultuur geleef het. Die teologiese werk van die Apologete was 'n goeie voorbeeld daarvan. Dit was duidelik 'n geval van die verinheemsing van die Christelike teologie in die Grieks-Romeinse kultuur.

Met die opkoms van die Konstantynse bedeling en die Bisantynse staatskerk verander sake in meer as een opsig: Ook dít was 'n paradigmaverskuiwing. Die owerheid raak direk betrokke by die kerk. Konstantyn se rol in die konsilies wat oor die Drieeenheid moes besluit, is die beste voorbeeld hiervan (vgl ook Van Aarde 1994:354vv).

Die klem verskuif ook na eenheid en eenselwigheid. Die kerk word die draer van die dominante kultuur, in plaas van vertaler van die evangelie in verskillende kultuurkontekste. Bosch maak trouens die stelling dat die verspreiding van die evangelie vanaf hierdie punt daarvan afhanklik gemaak is dat die kultuur van diegene aan wie die evangelie gebring is, voor die kultuuraanslag van die sendende kerk moes swig1.

Ons kan dus die gevolgtrekking maak dat die kerk en sy sending gedurende die Konstantynse periode deel geword het van die ryk se magspolitiek en daarom nie meer heeltemal vry was om sy evangeliese intuisie te volg nie. Die kerk se sending het dus 'n tweede (en miskien meer belangrike) moment bygekry, naamlik om die draer en legitimeerder van die sentrale, amptelike kultuur en ideologie te word.

Ironies genoeg was die heterodokse groepe in dié tyd ook met sending besig en op 'n manier wat dié van die vroeë kerk meer getrou gebly het. Vanweë hulle heterodokse status, kon hulle hulle slegs in die grensgebiede, dit wil sê ver van die magsentra, 
handhaaf. Die sendingveld was vir hulle 'n lewende realiteit. Die Ariaanse sending onder die Germane (Ulfilas) was een van die bekendste en mees suksesvolle gevalle. Die sendinguitreik van die Nestoriane in Boeddhistiese gebiede was minder suksesvol, maar uit die oogpunt van verinheemsing dalk meer interessant, omdat hulle op taamlik omvangryke skaal met akkommodasie en adaptasie geëksperimenteer het.

Die teokratiese droom lei in die geval van Bisantium tot dalk die mees voldonge voorbeeld van 'n Corpus Christianum wat die geskiedenis ooit gesien het ${ }^{2}$. Ironies genoeg het hierdie monolitiese grootheid uiteindelik minder in staat geblyk te wees om homself te handhaaf as die Westerse Christendom waar die kerk as laaste oorblyfsel van die Romeinse kultuur 'n skynbaar verlore stryd teen die oormag van 'n Germaanse barbaredom gevoer het. Van Leeuwen skryf (1966:177) hieroor soos volg:

De ondergang van het west-romeinse rijk had aan de kerk van Rome een bewegingsvrijheid geschonken, die de byzantijnse kerk nooit heeft kunnen verwerwen. Terwijl Byzantium zich een millennium langer dan het west-romeinse rijk staande wist te houden, zette de kerk van Rome zich aan de missioneringsarbeid onder de barbaren van west-Europa en droeg de keizerskroon over aan de barbarenkoning Karel de Grote. Byzantium daarentegen trachtte zijn theocratisch imperialisme met geweld aan de slavische volken op te dringen en putte zich langzaam maar zeker uit in een eindeloze oorlog, die wel een militaire zege bracht maar op het religieuze en culturele vlak een nederlaag betekende.

Die kerk het in die Weste dus meer subtiel te werk gegaan ... nie soseer uit keuse nie, maar uit noodsaak. Sending en kerstening van die Germaanse volkere het kragtige middele geword in hulle geleidelike 'beskawing' en die vorming van 'n nuwe WesEuropese Corpus Christianum. Laasgenoemde het egter nooit so ver ontwikkel as die Bisantynse voorbeeld nie, vanweë groter innerlike pluraliteit, die feodale gesagstruktuur en die feit dat die keiser en pous in 'n interafhanklike, maar ook voortdurende spanningsrelasie, met mekaar verkeer het (Van Leeuwen 1966:232-237).

Een van die wyses waarop die kerk inheems geword het, was deur homself in terme van die gangbare Romeinse reg te bedink en te definieer. So kry ons die opkoms van die juridiese kerkbegrip en die semantiese vervloeiing van begrippe soos fidelis, Christianus, Romanus en civis. Terselfdertyd is infidelis met barbarus en apostastis met perfidia gelykgestel (Van der Merwe 1984). Beide in die oostelike en westelike dele van die kerk het daar dus ' $n$ vergroeiing van kerk en kultuur plaasgevind, sodat dit eerlang nie meer moontlik was om die een sonder die ander te bedink nie. 
Kahl (1978:55) gee 'n uiteensetting hoe 'n teks soos Luk 14:15-24 (compelle intrare) deur Augustinus uitgelê is om gedwonge herkatolisering van apostate te regver$\mathrm{dig}^{3}$. Dit word gedurende die Middeleeue ontwikkel om geweldadige 'sending' in te sluit. Dieselfde denkontwikkeling lei ook tot die gedagte van die bellum justum, die geregverdigde wapenstryd, aanvanklik teen apostaatsgebiede en later teen halsstarrige heidene. Dit vorm later ook die teologiese basis vir die Kruistogte. So sien ons dat die Westerse Corpus Christianum uiteindelik dieselfde weg opgaan as die Bisantynse. Gedurende derde kruistog kom dit trouens op 'n gewapende konfrontasie tussen hulle neer wanneer die Kruisvaarders in plaas van Jenusalem Bisantium aanval, inneem en plunder, en so die einde van die Oosterse Corpus Christianum verhaas.

Die kruistogmentaliteit eindig nie met die mislukking van die laaste ekspedisie nie, maar word voortgedra in die herowering van die Iberiese skiereiland en latere militêre veldtogte in Noord-Afrika. Dit motiveer ook die Spaanse Conquista van Sentraal- en Suid-Amerika. Bosch sê hieroor:

... It can be argued that the roots of the later conquistadores and the entire phenomenon of the European colonization of the rest of the world lay in the medieval teachings on just war (Kahl 1978:66). On closer inspection one might even say that colonization was the 'modern continuation of the Crusades'.

(Bosch 1991:226)

Wanneer die Spaanse veroweraars in die sestiende eeu oor Sentraal- en Suid-Amerika storm, word hulle gewoonlik van priesters vergesel en sien hulle hulle vernietigende en moorddadige optrede dus volledig in ooreenstemming met die kerk se uitbreidingsopdrag. Met die oorname van die ryke van die Asteke en Inkas was een van die eerste politieke handelinge die afbreek van prominente altaar- en tempelpiramides en die oprigting van katedrale of kerke op dieselfde plek. Politieke imperialisme was ook kulturele en godsdienstige imperialisme. Sendelinge, soos Bartholomé de Las Casas en Antonio de Montesinos, wat hierdie praktyke sterk teengestaan het, was ver in die minderheid en het selde enige owerheidsteun geniet (Bosch 1991:236, 532).

Tog het daar ook ander menings geheers. Die Jesuiete het die leiding hierin geneem. Francisco Xavier wat sedert die helfte van die sestiende eeu in Indiē gewerk het, Matteo Ricci en Roberto DeNobili probeer volgens Hillman (1987:511) 'n derde epog in die kerk se geskiedenis van vleeswording inlei met hulle teorieë van adaptasie en akkommodasie. Ricci en sy opvolger in Sjina, Adam Schall, gebruik hulle kennis 
van wiskunde en sterrekunde om hulleself nuttig te maak aan die Sjinese hof. Terselfdertyd pas hulle hulle verkondiging aan om voorsiening te maak vir die tradisionele voorouerering van die Sjinese en hulle Confuciaanse etiek. Hulle werk word met sukses bekroon en in 1700 was daar reeds 300000 gedoopte Sjinese (Wiersinga 1959:82).

In 'n beleidsdokument van die Congregatio de Propaganda Fide van 1659 kom akkommodasie ook na vore, maar teen 1700 begin die gety teen die Jesuiete draai. Die Dominikaners en Franciskaners het hulle aanhoudend daarvan aangekla dat hulle die grens na sinkretisme oorgesteek het. Verskeie pouse soos Innocentius X, Clemens XI en Clemens XII spreek hulle ook teen so 'n gevaar uit. In 1744 plaas pous Benedictus XIV duidelike beperkinge op akkommodasie en word dit slegs nog in die geval van die mees aksidentele en formele aspekte van Christenskap en kerkwees toegelaat. In 1773 word die Jesuïete uit die sendingveld teruggeroep. Hillman (1987:511) konkludeer hierop: 'Where the Judaizers failed the Westernizers triumphed'.

Akkommodasie het streng gesproke dus nie tot 'n einde gekom in die RoomsKatolieke Kerk nie. Die veronderstelling was dat die innerlike aspek van evangelie en kerkwees (die depositum fidei) wesenlik is en onaangeraak moet bly (Bosch 1991:449). In praktyk het dit egter daarop neergekom dat die pendulum na die ander kant deurgeswaai het en dat 'the customs, laws, myths, symbols, practices, styles, gestures, conceptualizations and formulations of European Christians' normatief vir die ganse Rooms-Katolieke Kerk geword het (Hillman 1987:511). Die grondoorsaak van hierdie verwikkeling was volgens Hillman nie so seer die koestering van die depositum fidei nie, maar Westerlinge se essensiële, kulturele arrogansie. Die sending van die kerk is vertroebel deur 'n kultuurimperialistiese motief wat op sy beurt weer 'n politieke motief moes gehad het.

Terwyl die sending in die Rooms-Katolieke Kerk na die interne stryd met die Jesuïete ' $n$ insinking vertoon het, het die Protestantse sending op dreef gekom namate Protestantse lande ook koloniale moondhede geword het. So word die patroon herhaal wat hom vroeër in die Rooms-Katolieke sending voorgedoen het: sending se verband met kolonialisme en imperialisme ... 'n feit wat sendingwetenskaplikes al op baie maniere beskryf en bedink het, maar steeds 'n verleentheid vir die kerk bly. Selfs die Morawiese Broeders het verkies om in gebiede te werk waar Europese teenwoordigheid op een of ander manier gegeld het. Dat hierdie prentjie baie ingewikkelder is as wat dit op die oog af voorkom, moet dadelik toegegee word (vgl bv Bosch 1991:312). Aan die ander kant is dit feitlik ondenkbaar dat die sending binne hierdie historiese en politieke raamwerk nie van 'n ideologiese en kulturele superieuriteitsgevoel sou uitgaan nie. 
Die volgende ontwikkeling van belang was die opkoms van die drieselwe-ideaal in die Protestantse sending wat, ofskoon dit volgens Bosch (1991:450) Westerse kultuurwaardes uitgedra het, tog 'n soort dekolonisasie van jong kerke begin het. Origens het die Protestantse sending wat verinheemsing betref, nie veel anders verloop as die Rooms-Katolieke sending nie. Oënskynlik was daar meer vryheid vir lokale kerke om uitdrukking te gee aan hulle geloof en verstaan van die evangelie, maar dieperliggend was hulle steeds gebind aan die Westerse patrone van verstaan en uitdrukking. Bosch (1991:295) toon aan hoe die drieselwe-ideaal byvoorbeeld daarvoor verantwoordelik was dat jong kerke in bestaanspatrone ingedruk is wat hulle nie alleen in ' $n$ hoë mate van hulle kultuuromgewing vervreem het nie, maar ironies genoeg nog meer afhanklik gemaak het van Westerse ondersteuning.

Daar was verder ook nog die sogenaamde pedagogiese benadering, naamlik dat die jong kerke as ' $t$ ware tot volledige kerkwees opgevoed moes word, natuurlik met die veronderstelling dat die Westerse kerk en teologie die volwasse vorm verteenwoordig (Bosch 1991:292). Die verspreiding van die Westerse kultuur is ook vir die grootste deel van die Westerse sendinggeskiedenis as ' $n$ vanselfsprekende missionêre plig beskou, omdat blindweg aanvaar is dat die Westerse kultuur 'n Christelike kultuur is, of dat die inheemse kulture, vanweë hulle sondige en verwronge aard, geen basis kon bied vir Christenskap en 'n kerklike lewe nie. Bosch (1979:137) voeg hierby:

Die Duitse teoloog wat uiteindelik as ' $t$ ware die seël op hierdie hele ontwikkeling sou plaas, was Ernst Troeltsch. ... As historiese navorser kan hy nie anders oordeel as dat die Christelike godsdiens wat sy oorspronge betref, op geen uniekheid aanspraak kan maak nie. Sy uniekheid lê primer in wat hy die wêreld kan bied: geestelike waardes, beskawing, eenheid, die hoogste vorm van kultuur. 'Die huidige sending is die uitbreiding van die godsdienstige ideëwêreld van Europa en Amerika in enge samehang net die uitbreiding van die Europese invloedsfeer'. Sending beoog 'kultureel-geestelike opheffing'.

\subsection{Van inheemswording tot kontekstualisering}

Teen die einde van die vorige eeu het die besef begin deurdring dat die werklikheidsbegrip en wetenskapsbeskouing van die Aufklärung die Westerse kultuur en kultuurprodukte fundamenteel verander het en dat dit 'n gesekulariseerde kultuur geword het. '... When the IMC held its first plenary assembly on the Mount Of Olives in 1928, many American delegates had begun to have grave misgivings about the rise of secularism and the fact that, by and large, this was what the Western missions were exporting' (Bosch 1991:326). 
Die oplossing wat WE Hocking by die konferensie voorgestel het, was verbeeldingryk, maar het die moontlikheid ingehou dat die kerk nog dieper in die versmorende omhelsing van kultuur sou geraak. Hy het naamlik voorgestel dat die Christelike sending 'n vennootskap aangaan met die ander godsdienste om 'n bolwerk van religieusiteit teen die aangolwende sekularisme op te werp in voorbereiding van kulturele eenheid wêreldwyd. Die uiteindelike oogmerk van sending was dus die daarstelling van een wêreldkultuur.

Adaptasie en inheemswording het ook as temas by die Jerusalemse konferensie gedien. Kraemer beoordeel die konferensie se hantering daarvan egter as akademies, kunsmatig en steriel. Volgens hom is ' $n$ inheemse Oosterse kerk daar byvoorbeeld beskryf as 'a Christian church that was best adapted to meet the religious needs of these Eastern peoples, most congenial to Eastern life and culture, and most effective in arousing in the Eastern Christians the sense of responsibility (my kursivering)'. (Kraemer 1938:313, 315).

Die Jerusalemse konferensie van die Internasionale Sendingraad was egter ook die geleentheid waar baie konferensiegangers die teologie van Karl Barth vir die eerste keer verneem het, veral by monde van H Kraemer. Soos bekend, kry Kraemer die geleentheid om die missiologiese betekenis van dié teologie by die volgende konferensie van die ISR (Tambaram 1938) volledig uit te werk. In plaas van 'n verslag soos versoek, skryf hy die bekende werk, A Christian message in a non-Christian world, waarin hy onder andere van die Barthiaanse onderskeid tussen religie en Openbaring uitgaan. Dit was die begin van nuwe teologiese denke oor die verhouding tussen Openbaring en kultuur, 'n herbesinning wat die kerk self ook nie gespaar het nie. 'The dividing lines no longer ran between 'Christianity' and 'paganism', between the church and the world, but through the church as well. We are all, at best, "Christopagans"' (Bosch 1991:370). Die nie-Christelike wêreld waarna die titel van sy boek verwys, is nie die nie-Westerse wêreld nie, maar die ganse wêreld, dit wil sê met insluiting van die Weste.

Die kerk bestaan dus as geloofsgemeenskap en religie, as eskatologiese gemeenskap en kultuurgemeenskap, as liggaam van Christus en kultuurverskynsel. Alhoewel die kerk nie aan sy eie menslikheid, dit wil sê kulturele en religieuse inslag, kan ontsnap nie, ontneem dit die kerk nie van die verantwoordelikheid en plig om die menslike kant van sy bestaan en geskiedenis aan die kritiese ordeel van die Openbaring te onderwerp nie ${ }^{4}$.

$\mathrm{Na}$ aanleiding van hierdie dialekties-kritiese onderskeiding word in die volgende periode 'n nuwe teologie van kultuur en godsdiens ontwikkel, met Kraemer as een van die beste eksponente daarvan. Hy neem selfs standpunt teen Barth in oor laasgenoemde 
se onverbiddelike afwysing van die leer van 'n natuurlike of algemene Openbaring en spreek waardering uit vir die teologie van Brunner (Kraemer 1956:356-359). Oor die algemeen kan sy benadering egter as Barthiaans bestempel word.

Die dialektiese benadering tipeer ook sy standpunt oor inheemswording. Aan die een kant verwyt hy Westerse sendinginstansies hulle onvermoë 'to emancipate themselves from the cultural, mental, emotional and social frame in which they are accustomed to live and express their religious life' (Kraemer 1938:316). Aan die ander kant waarsku hy teen die neiging om die historiese en institusionele aspekte van die Christendom en sy boodskap as aksidenteel en uiterlik af te maak (Kraemer 1938:318).

Vanweë sy godsdienswetenskaplike agtergrond en jarelange ervaring as sendeling in Indonesië het Kraemer 'n sekere praktiese sin en realisme oor sending en inheemswording openbaar. Hy was minagtend teenoor diegene wat volgens hom inheemswording as 'n akademiese oefening wou bedryf. Aan die ander kant was dit onrealisties om van die jong kerke te verwag dat hulle sonder bystand van die ouer (Westerse) kerke moes aanpas en inheems word (Kraemer 1938:318).

Die bekende sendingwetenskaplike, J H Bavinck, het weer verkies in aansluiting by $\mathrm{H}$ Frick van die term possessio gebruik te maak. In plaas van akkommodasie, wat syns insiens 'n sinkretistiese gevaar ingehou het, beteken possessio dat die Christelike lewe die heidense lewensvorme in besit neem en nuut maak.

Het Christelijk leven neemt se in handen en keert ze in een geheel andere richting, ze worden wedergeboren en krijgen een volstrekt nieuwe inhoud ... Christus zelf ... vult elk ding, elk woord, elk gebruik met een nieuwe gedachte en een nieuwe gerichtheid. Dat is geen 'aanpassing', geen 'accommodatie', het is in wezen de rechtmatige in-bezit-neming door Hem, aan wie alle exousia, alle machtiging in hemel en op aarde geschonken is.

(Bavinck 1954:181vv)

Van der Westhuizen (1990:62) redeneer egter tereg dat possessio of toeëiening dui op die werk van die Heilige Gees. Dit kan dus nie eintlik as menslike werk beredeneer word of as 'n doelstelling in 'n sendingstrategie opgeneem word nie.

In die Rooms-Katolieke wêreld het 'n eie gesprek oor lokale akkommodasie en inheemswording aan die gang gekom. Verskeie pouslike ensiklieke sedert 1919 dui daarop dat die Rooms-Katolieke Kerk bestendig in die rigting van meer lokale hiërargiese verteenwoordiging en insette begin beweeg het (Bosch 1991:451). 
Vaticanum II verteenwoordig egter 'n duidelike mylpaal deurdat dit erkenning verleen aan die betekenis en rol van plaaslike kerklike gemeenskappe, en die ruimte skep vir meer lokale en etnies gekleurde liturgieë. Vaticanum II het natuurlik ook wegbeweeg van Latyn as liturgiese taal ten gunste van plaaslike tale.

In ongeveer dieselfde tyd het die begrip inkulturasie binne die Rooms-Katolieke Kerk posgevat. Afgelei van die volkekundige term enkulturasie word dit in 1962 vir die eerste keer gebruik deur J Masson. Dit word ook met die biskopsinode van 1977 gebruik en word daarna 'n algemene gebruiksterm binne Jesuïtiese geledere. In 1979 gebruik pous Johannes Paulus II dit in sy Catechesi tradendae, waarna dit ook spoedig in die res van die Rooms-Katolieke teologie 'n gebruiksterm word.

Hillman (1987:510) beskryf inkulturasie in samehang met begrippe soos katolisiteit, akkommodasie, adaptasie, inheemswording, kontekstualisering en inkarnasie. Die bedoeling van inkulturasie is

... calling the church into historically tangible and culturally integrated existence throughout the inhabited earth. It is through obedience to the principle of inculturation, with its acceptance of humankind's changing historical condition and invincible cultural pluralism, that the church is supposed to become culturally catholic, and thus a universally intelligible 'sign raised up among the nations inviting all who have not yet believed.

(Vatican I, DS 1794)

Verder neem inkulturasie God se handelinge in die geskiedenis as voorbeeld:

Against a recurring monophysite tendency to 'divinize' the church by regarding it in an overly spiritualized and ahistorical manner that minimizes or even denies the ephemeral nature of the historically conditioned and culturally limited elements in its life, the incarnational approach takes seriously the implications of human finitude, flesh, history, creativity, temporality, vulnerability and fallibility .... The church must not pretend to be less human or more divine than the Lord of history himself .... After the manner of the divine Logos, the church must go out of herself, emptying herself of power, foreign riches and alien accretions, thus opening herself to modes of human existence, experience, expression and celebration that were not hers previously. The Church, 
in other words, it to make herself completely at home among each people in the same authentically human way that Jesus was at home in Nazareth.

(Hillman 1987:512)

Amalorpavadass (1987:205) vestig die aandag op die universeel teologiese en kerklike implikasies van die gedagtes wat inkulturasie ten grondslag lê. Indien 'n mens nog hoegenaamd van die Westerse kultuur as 'n Christelike kultuur kan praat, sal dit slegs een van vele Christelike kulture wees: '... there can be as many Christian cultures as there are cultures in the world'.

Soos te verstaan, moet inkulturasie binne die Rooms-Katolieke teologie in verband gebring word met ander sleutelbegrippe wat daarin funksioneer, soos inkarnasie, sakrament en vervulling.

A theological justification of this point is based on the plan of God to bring everything under Christ the Head (Eph 1:9-10). Through the mystery of incarnation, he assumes the whole of creation in order to redeem it and unify it. Nothing is saved unless it is assumed, and everything that has been created must be saved. The recapitulation of all things in Christ includes not only souls but the whole person and all people, all that is human, not only cultures, but religions also. The church, which continues the mission of Christ as 'the universal sacrament of salvation' (LG 42), cannot save anything unless she assumes it in order to transform it.

(Amalorpavadass 1987:205)

Inkulturasie het ook in die Protestantse wêreld uitgeslaan. Volgens Bosch (1991:452) was dit hoofsaaklik die Evangelicals wat daarin belang gestel het, aangesien die Ecumenicals meer in bevrydingsteologiese perspektief geinteresseerd was. In 1978 belê die Lausanne Komitee vir Wêreldevangelisasie 'n beraad oor evangelie en kultuur, te Willowbank, Bermuda. Dit lei tot die sogenaamde Willowbank Verslag waarin vir 'n model van dinamiese ekwivalensie (Eugene Nida) gekies is.

Die laaste ontwikkeling waarna ons kyk, is kontekstuele teologieè. Ukpong (1987) het twee hoofmodelle onderskei, te wete 'n verinheemsingsmodel en 'n sosioekonomiese model. Albei is ideologiekrities en werk in 'n mindere of meerdere mate met 'n Marxistiese verstaan van mag, eksploitasie en bevryding. 
Hoewel daar eers in 1972 begin is om die begrip kontekstualisering in hierdie tegniese betekenis te gebruik, sê Ukpong (1987a:278) tereg dat dit 'n nuwe manier van kyk verteenwoordig na die sake wat lank reeds bekend is (en waarvan ons die meeste reeds oorsien het). (In eie geledere het Van der Westhuizen reeds in 1984 die begrip kontekstualisering in 'n missiologiese en opleidingsverband ontleed en bespreek.)

Bosch stel dat die nuwigheid van die kontekstuele benadering veral op epistemologiese vlak lê.

Whereas, at least since the time of Constantine, theology was conducted from above as an elitist enterprise (except in the case of minority Christian communities, commonly referred to as sects), its main source (apart from Scripture and tradition) was philosophy, and its main interlocutor the educated non-believer, contextual theology is theology 'from below', 'from the underside of history', its main source (apart from Scripture and tradition) is the social sciences, and its main interlocutor the poor or the culturally marginalized ...

(Bosch 1991:423)

Hy som die kenmerke van die nuwe epistemologie soos volg op:

* 'n Diepgaande wantroue van Westerse geleerdheid en wetenskap, met insluiting van Westerse teologie, omdat dit Westerse belange legitimeer en neerkom op 'n verfynde voortsetting van die eksploitasie waaraan die Weste, weereens met insluiting van die Westerse kerk, hom so lank skuldig gemaak het.

* 'n Ontkenning dat die werklikheid iets is wat bloot verduidelik of verklaar moet word. Die werklikheid is in die eerste plek die menslike werklikheid van hier en nou. Die wetenskaplike/teoloog het die verantwoordelikheid om dit te verbeter of te transformeer.

* 'n Beklemtoning van 'commitment' as die eerste teologiese daad, en spesifiek teenoor die verontregtes en gemarginaliseerdes. Indien die teologie geloofwaardigheid wil wees, moet dit langs en in solidariteit met die verontregtes beoefen word. 
* Die klem op die daadkarakter van teologie. Teologie kan nie 'n verwyderde, ivoortoringbedryf wees nie. Die uitgangspunt is ortopraxis, nie ortodoksie nie.

* Prioritisering by wyse van 'n hermeneutiese sirkel wat begin met ervaring (van marginalisering). Daarná kom refleksie en teoretisering. Die een is egter nie minder belangrik as die ander nie.

Oor wat alles as kontekstuele teologieë beskou moet word, is daar nie duidelikheid nie (vgl ook Tienou 1993:247). Ukpong sluit die verskillende bevrydingsteologiese variante daarby in, terwyl Bosch verkies om dit nie te doen nie. Wat wel duidelik is, is dat kontekstuele teologie aan bevrydingsteologie verwant is (vgl ook Van der Westhuizen 1990:58).

\section{UITDAGINGS AAN KERK EN TEOLOGIE}

Vandag lê die oorwig van Christene nie meer in Europa en Noord-Amerika nie. Ramings dui daarop dat 29 persent in Europa en Noord-Amerika woon, 26 persent in Suid-Amerika en 30 persent in Afrika en Asië (Kritzinger 1994:108). Die Christendom het waarlik 'n wêreldwye godsdiens geword met die 'Derde Kerk' in 'n toenemend dominante rol (vgl Bühlmann 1977). Die afgelope drie dekades het ook 'n sterk opbloei in teologiese publikasies uit dié oord gesien.

Dit bring mee dat temas soos inheemswording, inkulturasie en kontekstualisering groter aktualiteit geniet as ooit tevore. Dit gaan egter nie net om die implikasies vir sending nie, die teologiese implikasies daarvan is net so belangrik. Vraagstellings wat deur dié debat opgewerp word, dwing die Westerse teologie naamlik tot fundamentele selfondersoek. Daar word veral met nuwe oë gekyk word na die wyse waarop die evangelie en die kerk in die Weste inheems geword het.

\subsection{Die Westerse Christendom as resultaat van inheemswording}

Die Westerse Christendom moet ook gesien en bedink word as die resultaat van 'n lang proses waarin kerk en evangelie 'n plek gevind het in komplekse, steeds veranderende samelewings en kulture. Die kerk het terselfdertyd egter ook 'n kerstende uitwerking op sy omgewing uitgeoefen.

Ons kyk vervolgens na enkele aspekte wat hiermee verband hou. 


\title{
3.1.1 Ontlening en/of sinkretisme
}

Hoewel die beginsel van adaptasie en inheemswording lank reeds in die Sendingwetenskap aanvaar word, was (of is) baie teoloë onwillig om te aanvaar dat dié beginsel ook na die vroeë kerk teruggevoer moes word. J H Bavinck sê byvoorbeeld nog in 1954

\begin{abstract}
Paulus en zijn medestrijders brachten niets anders dan alleen het evangelie. Maar reeds toen het Christendom langs allerlei kanalen binnensijpelde in Frankryk, Engeland, Nederland, Duitsland en andere landen van Noord-Europa, was het nauw verbonden aan de GrieksRomeinse cultuur, die gaandeweg de volkeren van die landen overwon.
\end{abstract}

(Bavinck 1956:106)

Die vraag is natuurlik of Paulus en sy medestryders inderdaad niks anders as die suiwer evangelie gebring het nie. En dan gaan dit nie alleen om kulturele vorme en aanhangsels nie. Dit gaan ook om hulle verstaan van Jesus en sy evangelie, en die rol wat hulle konteks daarin gespeel het.

Kraemer (1938:311) gee reeds in 1938 die moontlikheid toe dat Paulus aan die taal, metafore en paradigma van misteriekultusse ontleen het in sy verstaan en uiteensetting van Christus se kruisdood. Ons het vroeër verwys na diegene wat beweer dat Paulus reeds begin het met die 'vertaling' van evangelie en kerk in die Hellenistiese konteks. Of dit na persoonlike, eksistensiële motiewe of missionêre motiewe teruggevoer moet word, is nie duidelik nie. Die geskiedenis toon egter dat sy verstaanspoging die evangelie vir baie Hellenistiese mense toeganklik gemaak het (hoewel dit hom in onguns by die Jode gebring het).

Aan die ander kant, sê Kraemer, het dit nie beteken dat die uniekheid van die Christendom deur sulke ontlenings geaffekteer is nie, omdat dit duidelik is dat die godsdienspatroon van die kerk wesenlik van dié van die misteriekultusse verskil het. Buitendien kan nie alle ontlenings as sinkretisties beskryf word nie, omdat dit 'n normale religieuse verskynsel is. Ook die Ou Testament getuig in oordaad daarvan. Die godsdiens van Israel het baie reste van kulture en godsdienste bevat waarmee hulle oor eeue in aanraking gekom het.

H Gunkel het in 1903 beweer dat die Christendom 'n sinkretistiese godsdiens is, bedoelende dat dit in oorsprong en vroeë ontwikkeling sinkretisties was, maar Kraemer (1956:395) vra hoe dit moontlik kan wees dat so 'n godsdiens hom agterna hardnekkig verset teen die algemene Hellenistiese patroon van sinkretisme. Verder hang baie af van die manier waarop die begrip sinkretisme opgeneem word. 
Dit moet toegegee word dat godsdienste wat 'n monisties-panteïstiese grondpatroon het, geneig is tot 'n relatiwistiese, konvergerende visie van godsdienste en dat ' $n$ kultuur van sinkretisme natuurlikerwys posvat waar sulke godisdienste saam aangetref word (soos in die Hellenisme en Indië). Dan is daar ook godsdienste wat voorgee dat hulle alle godsdienste omsluit en oorkoepel (byvoorbeeld die Manicheisme en die Bahai) en wat spesiale gevalle van sinkretisme verteenwoordig. Sinkretisme beteken egter nie dat godsdienste blindelings vermeng nie. Dit kan eerder as 'n soort simbiotiese verhouding beskryf word waar godsdienste 'n onderliggende eenheid erken, met mekaar kommunikeer en vrylik van mekaar oorneem, sonder om hulle essensiële identiteite prys te gee.

In die geval van die Christendom, betoog hy, het ons te doen met 'n godsdiens wat wesenlik anti-sinkretisties is, omdat dit 'n profetiese openbaringsgodsdiens is (soos onk die Judaisme en die Islam). Al die ander godsdienste word 'naturalist religions of trans-empirical realization' genoem, met ander woorde gaan terug op 'n monisme en moontlik ook 'n panteisme (Kraemer 1938:142).

Pannenberg verwys ook na Gunkel se stelling en Reischle (1904:36) se argument daarteen (wat min of meer dieselfde as Kraemer s'n was). Hy maak daaroor die volgende opmerking:

This judgment (of Reischle) obviously underestimates the significance of the Hellenistic material for the formative process of the religious history of early Christianity. Ideas of epiphanies, mystery-type conceptions of the sacraments, platonizing doctrines of God, were by no means only incidentally taken over and turned into statements that were somehow completely independent of such contents, but rather became constitutive - or co-constitutive - elements of the specifically Christian understanding of revelation. To this extent, the statement about the syncretistic character of Christianity is correct. But this concept does not assert that the different religious elements have equal rights (against Reischle). Rather, in Plutarch's interpretation of the term ... an integrating principle prior to the different elements is presupposed. This function was fulfilled in the Hellenistic world by the philosophical logos as the common denominator of the different religious symbolizations, while in Christianity, on the other hand, it was fulfilled by the person of Jesus and the redemptive event of his death and resurrection - in other words, by the logos incarnated in Jesus. The latter formula expresses the universal relevance of what happened in Jesus, and the inexhaustible assimilative 
and regenerative power of Christianity corresponds to this. The fact that Christianity is syncretistic to an unusual degree thus expresses not a weakness but the unique strength of Christianity.

(Pannenberg 1971:87, n 37)

Hierbenewens was die vroeë kerk ook nog eksklusief. Die Christendom se krag in sulke situasies was dus daarin geleë dat dit die beste van ander godsdienste en kulture waarmee dit in aanraking kom, kon oorneem, met sy eie tradisie en verstaan integreer en hom so kon versterk. Hoewel alle godsdienste in 'n mindere of meerdere mate dié vermoë het, het die Christendom van die Hellenisme hierin uitgemunt?

\subsubsection{Verandering van konteks en verskuiwing van betekenis}

Bosch haal Paul Ricoeur aan om te betoog dat alle teologie (en verkondiging) kontekstueel is. "Every text is an interpreted text ... in a sense the reader "creates" the text when she or he reads it. The text is not only "out there", waiting to be interpreted; the text "becomes" as we engage with it' (Bosch 1991:423). Die leser is die gekontekstualiseerde leser.

Konteks beteken in hierdie geval nie net die fisiese, kulturele of religieuse omgewing nie. Dit het ook te doen met die 'lesers' as ingebed in die kultuur en lede van 'n gemeenskap. Dit het te doen met wat hulle as werklikheid en waarheid aanvaar en die ideologiese kragte waaraan hulle onderworpe is (vgl Van der Merwe 1996:676-680).

Wat van die evangelie en die kerk 'n spesiale geval maak, is dat dit bedoel is om grense te oorskry, om geen grens as 'n verhindering te sien nie, maar elke nuwe konteks aanvaar as 'n uitdaging om die koninkryk van God te verkondig. Dit het te doen met die wese en aard van die evangelie en die kerk om in verskillende en selfs uiteenlopende kontekste tuis te kom. Wanneer ons oor kontekstualisering, verinheemsing en/of inkulturasie praat, praat ons dus nie van randsake nie, maar oor wat vir die kerk en verkondiging natuurlik is of behoort te wees.

Al sou 'n mens saam met Kraemer wil argumenteer dat die uniek evangeliese nie wesenlik deur aanpassings aan vreemde kultuuromgewings geaffekteer is nie, kan nie ontken word dat subtiele teologiese betekenisaanpassings of aksentverskuiwings normaalweg in so 'n proses plaasvind nie. Dit geld selfs in die geval van 'vertaling', dit wil sê waar inheemswording of inkulturasie op patroon van Nida se dinamiesekwivalente-vertaalbeginsel bedink of nagestreef word. Die geakkumuleerde effek daarvan kan oor 'n lang tydperk neerkom op taamlike verskuiwings in betekenis of aksent. Dit is dan inderdaad ook so dat die Christendom oor 2000 jaar heelwat 
verander het en dat dit buitendien 'n geweldige interne pluraliteit ontwikkel het. Bosch is reg as hy sê dat 'n theologia perennis nie moontlik is nie. Tienou (1993:249) sê dat die huidige Christendom polisentries geword het. Die vraag is egter of dit nie reeds van vroegsaf so was nie.

Die vraag bied homself aan of daar iets soos 'n kontinue kernidentiteit bestaan, 'n soort subminimum waarsonder Christenskap nie moontlik sou wees nie. Hierop kan verskillende soorte antwoorde gegee word, byvoorbeeld 'n godsdienshistoriese, 'n teologiese en ' $n$ belydende antwoord. Met eersgenoemde en dalk ook die tweede bestaan die moontlikheid om soveel verskillende vlakke en kante van die probleem te onderskei en te oorweeg dat daar nouliks by ' $n$ antwoord uitgekom sal kan word. Daarom is die derde manier waarskynlik die mees haalbare. Die minimum belydenis is dan die vroegste formele belydenis bekend: Jesus Christus is die Here (vgl ook Bosch 1991:427).

\subsubsection{Ortodoksie en heterodoksie}

Wanneer in aanmerking geneem word watter kragte en faktore in die verlede op die kerk en sy leer ingewerk het, volg dit vanself dat daar ook met nuwe oë gekyk moet word na dit wat in die verlede as klassieke Christelike leer beskou is, asook die wyse waarop ortodoksie en heterodoksie onderskei is.

Bosch het dikwels in gespreksgeleenthede die hipotetiese vraag gevra hoe die Christendom sou gelyk het as dit nie via Europa na die wêreld gekom het nie, maar byvoorbeeld via Asië of Afrika.

Die wete dat die kerk 'n bepaalde nuttigheidswaarde as vennoot in 'n burgerlikgodsdienstige bestel kan hê en in die verlede dikwels as legitimeerder en draer opgetree het van ' $n$ kultuur, waarheid- en waardestelsel wat bepaalde belangegroepe bevoordeel (en ander benadeel) het, moet noodwendig ' $n$ rol speel by die moderne herevaluering van vorige teologiese en leerontwikkeling. Bosch (1991:424) verwys in dié verband na Nietzsche se 'hermeneutiek van suspisie'. Dit spreek vanself dat 'n mens dié soort hermeneutiek veral sal toepas op amptelike leerontwikkeling vanaf die Konstantynse era.

Die Kontekstuele Teoloë kan egter nie sonder meer toegegee word dat die verontregtes en gemarginaliseerdes die vindplek van waarheid is nie. Daarom moet die soort groepsdinamiek en -mentaliteit, asook ideologiese kragte, wat in hulle geval van toepassing kon wees; ook in aanmerking geneem word. Dit geld dan die vroeë kerk, die vervolgde Christendom en die sogenaamde sektes.

Dan is daar ook die verinheemsingsfaktor waarmee rekening gehou moet word. Ons het vroeër verwys na vroeë teoloë se ontlening aan Grieks-filosofiese idees en stelsels. Jaeger (1947:2vv) wys daarop dat ofskoon hierdie idees en stelsels in die vorm 
van gesekulariseerde filosofie aangebied is, dit in der waarheid deel uitgemaak het van verfynde Griekse teologie. Deur sonder meer daarby aan te sluit, kon die vroeë teologie subtiel van 'n Bybelse Godsbegrip na 'n Grieks-filosofiese verskuif het ${ }^{8}$. Derglike agtergrondskennis kan 'n groot verskil maak by die moderne herevaluering van vroeë ortodoksie (en heterodoksie).

Heterodokse ontwikkelings word ingevolge hierdie benadering ook belangrike navorsingsvelde, veral met betrekking tot die kragte en faktore wat daarin 'n rol gespeel het, terwyl oorweeg moet word of sulke ontwikkelings nie die gevolg was van lokale inkulturasie of adaptasie nie.

Laastens is meer diepgaande kennis nodig van die nie-Christelike kultuurwêrelde wat die kerk in Europa betree het en so effektief met sensuur in die vergetelheid gedryf het. Beter kennis en insig sal ons moontlik in staat stel om diepliggende Europese denkpatrone te identifiseer en so tot 'n beter begrip te kom van vroeë Europese teologiese denke.

\subsection{Implikasies vir jong kerke en sending}

Kontekstualisering, verinheemsing en inkulturasie geniet tans, soos reeds genoem, 'n besondere aktualiteit in die sending en die sogenaamde Derde Kerk. Hiervan getuig die stortvloed publikasies en die debat wat die afgelope twee dekades aan die gang is 9 . Daar bestaan ook 'n organisasie wat Derde-Wêreldse teoloë saamsnoer, te wete EATWOT ('Ecumenical Association of Third World Theologians'), wat as ' $n$ forum en 'n soort verrekeningskantoor ('clearing house') vir die debat dien.

Die duidelikste gevolg van die bewussyn van inheemswording en inkulturasie is die ontwikkeling van eie inheemse teologieë, geïnkultureerde kerke en inheemse Christelike kulture. Die meeste van die teologiese pogings is duidelik eksperimenteel. Inkulturasie kan net tot 'n sekere hoogte deur teoloë beïnvloed of gestuur word, aangesien dit iets is wat in die siel van die lokale kerk gebeur. Bosch (1991:453) sê dat die Heilige Gees en die plaaslike Christelike gemeenskap (meer spesifiek die gewone gelowiges) die eintlike agente vir inkulturasie is. Inkulturasie beteken dat elke volk en kultuur toegelaat word om self Christus te leer ken, as ' $t$ ware 'n eie geskiedenis met Hom te begin. Sendelinge en teoloë is hoogstens medewerkers, nie bewerkers nie.

Inkulturasie volg bewustelik die inkarnasiemodel, met spesifieke verwysing na die kenotiese aspek. Die evangelie neem vlees en liggaam aan wanneer dit in ' $n$ volk en sy kultuur inkarneer. Dit gaan dus nie so seer om die voortplanting van die kerk nie, maar om die herhaalde hergeboorte van die kerk in nuwe kulture en kontekste (Bosch 1991:454). 
Enige Westerse teoloog wat die Derde-Wêreldse Christendom betree, kom gou agter dat baie van die grense wat hy/sy tot nou wesenlik geag het, hulle betekenis verloor en sekere vaste aannames nie meer so seker lyk nie.

* Die duidelike grense tussen kerke van verskillende tradisies (Calvinisties, Luthers, Anglikaans, selfs Rooms-Katoliek) vervaag byvoorbeeld. In Afrika beweeg Christene gemaklik van die een denominasie na die ander, of besoek ander denominasies om daar van funksies te baat wat in hulle eie kerk afwesig is. Dit is nie 'n geval van 'n marksituasie nie, eerder die gevolg van 'n holistiese, komplementêre kerkbeskouing.

* Die duidelike onderskeid tussen ortodoksie en heterodoksie vervaag ook, waarskynlik omdat die leer as sodanig nie dieselfde gewig as in die Westerse kerke dra nie.

* Sinkretisme is ' $n$ aktuele en dringende vraagstelling. Baie Christene vind dit nie vreemd om hulle ook nog tot tradisionele magiërs of mediums te wend nie. Kraemer het van dieselfde tendens in Indonesië getuig. Dan is daar ook nog die sterk groei van die Onafhanklike Kerke in Suider-Afrika met wat vir Westerse kerke en teoloë na 'n sinkretistiese inslag lyk. Hierdie saak lê by die hart van inkulturasie (vgl ook Nicholls 1979:28-36).

Tereg wys Bosch (1991:455-457) ook op die beperkinge en gevare verbonde aan verinheemsing en inkulturasie. Ons noem slegs enkele daarvan:

* Inkulturasie beteken nie dat ' $n$ inheemse kultuur sonder meer en onkrities deur die kerk aanvaar en onderskryf behoort te word, bloot omdat dit vir die mense sin uitmaak nie. Inkulturasie moet dus ook 'n evangeliese, normatief-kritiese kant hê.

* Bosch haal Andrew Walls aan wat sê dat hier twee beginsels aan die werk is:

- Die beginsel van inheemswording wat leer dat die evangelie tuis is in alle kulture en dat alle kulture potensieel tuis is in die evangelie.

- Die 'pelgrimsbeginsel' wat leer dat die aanvaarding van die evangelie ons uit pas bring met elke kultuur. 
Dieselfde Walls sê ook dat ware inkulturasie beteken dat die evangelie die bevryder van kulture is. Dit staan teenoor die gedagte dat die kerk godsdienste en kulture vervul. Dit stem ooreen met Van der Westhuizen (1990:57) se waarskuwing dat 'kontekskonservering' maklik oorspan kan word, in welke geval kontekstualisering die vernietiging van die evangelie word. 'Dit gebeur wanneer Christus só Afrikaans word dat hy nooit Joods geword het of nooit weer iets anders kan word nie .... Oorspanne kontekstualisering maak van die konteks die god en so kry ons dan kontekstuele gode wat natuurlik afgode is'.

* Partikulariteit beteken nie isolasie nie, ook nie fragmentering van die basiese evangelie of die Hoof, Jesus Christus, nie. Inkulturasie beteken in 'n sekere sin ook interkulturasie. 'n Voortdurende osmose tussen teologieë van die hele wêreld word bedoel. Die katolisiteit en ekumenisiteit van die kerk mag nie verwaarloos word nie, nie alleen omdat dit as sodanig belangrik is nie, maar ook omdat die gemeenskaplike geloof so tot uitdrukking kom.

Terwyl die huidige uitdaging daarin geleë is dat evangelie, kerk en teologie in uiteenlopende kulturele kontekste grondvat en werklik inheems word, sal 'n toekomstige uitdaging waarskynlik daaruit bestaan dat hierdie pluriforme, plurale, katolieke kerk die sentrale en universele belydenis dat Jesus die Here is (ook van die kerk), saam kan bely.

\section{TEN SLOTTE}

Kontekstualisering, inheemswording en inkulturasie bied nie alleen uitdagings aan die sending van die kerk nie, dit bied ook die geleentheid aan die kerk en teologie om tradisionele gegewenhede en uitgangspunte te heroorweeg. Dit hou trouens die moontlikheid in dat die teologie tot ' $n$ nuwe interpretasie en verstaan van die kerk en sy roeping in die wêreld kan kom.

\section{Eindnotas}

1 Dit was natuurlik slegs waar in die geval van die sentrale kerk, aangesien ketterse groepe met 'n sekere mate van sukses aan die rand van die ryk of selfs daarbuite gewerk het.

2 Vgl Botha (1996) vir ' $n$ historiese oorsig van die Corpus Christianum.

3 Vir die missiologiese betekenis van Luk 14:15-24; vgl ook die ontleding in Van der Merwe 1994:428-430. 
4 Vergelyk hieroor opmerkings in Van der Merwe 1996:681-683.

5 'n Student van die hoog aangeskrewe Brede Kristensen.

6 Nicholson (1978:122-124) toon aan dat hierdie onderskeid 'n geskiedenis het. Hy betoog dat Kraemer onvoldoende godsdiensfenomenologiese argumente vir die onderskeid aanbied, as gevolg waarvan die afleiding gemaak moet word dat dit kwasi-fenomenologies is en daarom eerder as 'n teologiese onderskeid hanteer moet word.

$7 \mathrm{Vgl} \mathrm{ook} \mathrm{die} \mathrm{interessante} \mathrm{werk} \mathrm{van} \mathrm{Weltin} \mathrm{(1987).}$

8 Oor die toeëiening van die Grieks-filosofiese godsbegrip deur vroeë teoloë, vgl Pannenberg (1971:117-183).

9 Vergelyk byvoorbeeld Bevans (1991) wat, ofskoon ietwat verouderd, nogtans interessante inligting bevat.

10 Vergelyk Van Aarde (1994:359-361) se bespreking van 'n Afrika-poging om tot 'n inheemse Christologie te kom.

\section{Literatuurverwysings}

Allen, R [1913] 1962. Missionary methods: St Paul's or ours? Grand Rapids: Eerdmans.

Amalorpavadass, D S 1987. Church and culture, in Komonchak 1987:201-206.

Bavinck, J H 1954. Inleiding in de Zendingwetenschap. Kampen: JH Kok.

Bevans, S \& Thomas, N E 1991. Selected annotated bibliography on Missiology: Contextualization/Inculturation/Indigenization. Missiology 19/1:105-108.

Bosch, D J 1974. Het evangelie in Afrikaans gewaad. Kampen: Kok.

- 1979. Heil vir die wêreld. Pretoria: NG Kerkboekhandel.

1991. Transforming mission: Paradigm shifts in Theology of Mission. Maryknoll: Orbis Books.

Botha, S J 1996. Die Corpus Christianum in die Middeleeue. HTS 52/4, 800-819.

Bühlmann, W 1977. The Third Church. Maryknoll: Orbis Books.

Heussi, K 1956. Kompendium der Kirchengeschichte. Zwölfte Auflage. Tübingen: JCB Mohr.

Hillman, E 1987: Inculturation, in Komonchak 1987:510-513.

Jacobs, D R 1993. Contextualization in mission, in Phillips 1993:235-244.

Jaeger, W 1947. The theology of the early Greek philosophers. Oxford: Clarendon Press (soos aangehaal in Pannenberg 1971:123). 
Kahl, H D 1978. Die ersten Jahrhunderte des missiongeschichtlichen Mittelalters:

Bausteine für eine Phänomenologie bis ca 1050, in Schäferdiek 1978:11-76.

Komonchak, J A, Collins, M \& Lane, D A (eds) 1987. The new dictionary of theolo-

gy. Dublin: Gill \& Macmillan (aangehaal as Komonchak 1987).

Kraemer, H 1938. A Christian message in a non-Christian world. London: Edinburgh House.

1956. Religion and the Christian faith. London: Lutterworth Press.

- 1963. Godsdiensten en culturen: de komende dialoog. 's-Gravenhage: Boekencentrum NV.

Kritzinger, J J, Meiring, P G J \& Saayman, W A 1994. On being witnesses. Halfway House: Orion Publishers (aangehaal as Kritzinger 1994).

Krüger, J S 1988. Conditionality, religious experience and conceptualisation, in Mouton 1988:209-222.

1995. Along edges: Religion in South Africa: Bushman, Christian, Buddhist. Pretoria: Unisa.

Mouton, J, Van Aarde, A G \& Vorster, W S (eds) 1988. Paradigms and progress in theology. Pretoria: HSRC.

Nicholls, B J 1979. Contextualization: A theology of gospel and culture. Downers Grove, Illinois: InterVarsity Press.

Nicholson, W I 1978. Toward a theology of Comparative Religion: A study in the thought of Hendrik Kraemer and Wilfred Cantwell Smith. Ann Arbor: University Microfilms International.

Pannenberg, W 1971. Basic questions in theology, Vol II. London: SCM Press.

Phillips, J M \& Coote, R T 1993. Toward the twenty-first century in Christian mission: Essays in honor of Gerald H Anderson. Grand Rapids: WB Eerdmans.

Reischle, M 1904. Theologie und Religionsgeschichte. Tübingen (aangehaal deur Pannenberg 1971:87).

Schäferdiek, K (Hrsg) 1978. Die Kirche des früheren Mittelalters. München: Kaiser

Verlag. (Kirchengeschichte als Missionsgeschichte Band II.)

Tienou, T 1993. Forming indigenous theologies, in Phillips 1993:245-252.

Tlhagale, B s a. The inculturation debate: A Southern African perspective. Pretoria.

Ukpong, J S 1987. What is contextualization? NZM 43/3, 161-168.

1987a. Contextualisation: A historical survey. Afer 29/5 \& 29/6.

Van Aarde, A G 1994. Kultuurimperialisme as 'n hermeneutiese dilemma: Eerstewêreldse en Derde-wêreldse perspektiewe op Jesus as die Seun van God. HTS 50/1, 345-367. 
Van der Merwe, P J 1984. Doop, sending en die opkoms van die juridiese kerkbegrip. HTS 40/3, 62-67.

- 1994. Oorreding in evangelisasie. HTS 50/1 \& 2, 423-453.

- 1996. Kerk en kultuur ... 'n godsdiens-teologiese perspektief. HTS 52/3, 671692.

Van der Westhuizen, H G 1984. Beter kontekstualisering van ons teologiese opleiding. Theologia Viatorum 12/1, 56-63. 1990. Kerk en kerstening. Pretoria: Kital.

Van Leeuwen, A T 1966. Het Christendom in de wereldgeschiedenis. Hilversum: Paul Brand.

Weltin, E G 1987. Athens and Jerusalem: An interpretative essay on Christianity and classical culture. Atlanta: Scholars Press. (AAR Studies in Religion 49.)

Wiersinga, H A 1959. Geschiedenis van de zending. Kampen: JH Kok. 